\title{
Valuing Public Transport Customer Amenities: International Transit Agency Practice
}

\author{
Chris De Gruyter \\ RMIT University \\ Graham Currie \\ Monash University
}

\begin{abstract}
Public transport customer amenities cover a range of measures that can enhance the quality of the passenger experience, such as information provision and station quality. While much research has determined the value that users place on amenities, there is little understanding of current practice in the use of customer amenity valuations in project appraisal. A survey of transit agencies in 11 cities (Melbourne, Sydney, Brisbane, Perth, Auckland, London, Paris, Toronto, Vienna, Oslo, and Singapore) was undertaken and showed that Australasian cities generally have widespread inclusion of customer amenities as part of advanced appraisals for all relevant types of public transport projects. Australasian practice tends to include customer amenities more frequently in project appraisal than London, Singapore, and Oslo. Paris, Toronto, and Vienna rarely (if at all) include customer amenities in these appraisals, although they adopt advanced appraisals for some projects. While agencies generally use published sources of customer amenity values specific to their country, Toronto and Singapore tend to use customer amenity values from London, highlighting a lack of local customer amenity values.
\end{abstract}

Keywords: Transit agency, public transport, customer amenity, valuation, project appraisal

\section{Introduction}

A diverse range of factors can affect the quality of public transport from the customer perspective. Typically, these elements are classified into "hard" factors (mode, service frequency, right-of-way, operating hours, fares) and "soft" factors (Fearnley et al. 2015). Soft factors are commonly referred to as customer amenities and cover a range of ancillary improvements that are not directly related to operations or service quantity but can enhance the quality of the passenger experience (Currie, Scott, and Tivendale 2013). Examples of customer

(C) 2020 Chris De Gruyter and Graham Currie https//doi.org/10.5038/2375-0901.22.1.2

ISSN: 1077-291X | Licenced under Creative Commons License Attribution - Noncommercial 4.0

The Journal of Public Transportation is published by the Center for Urban Transportation Research at the University of South Florida 
amenities include information provision, passenger facilities, station/stop quality, and personal security measures. Figure 1 shows a classification of public transport customer amenities.

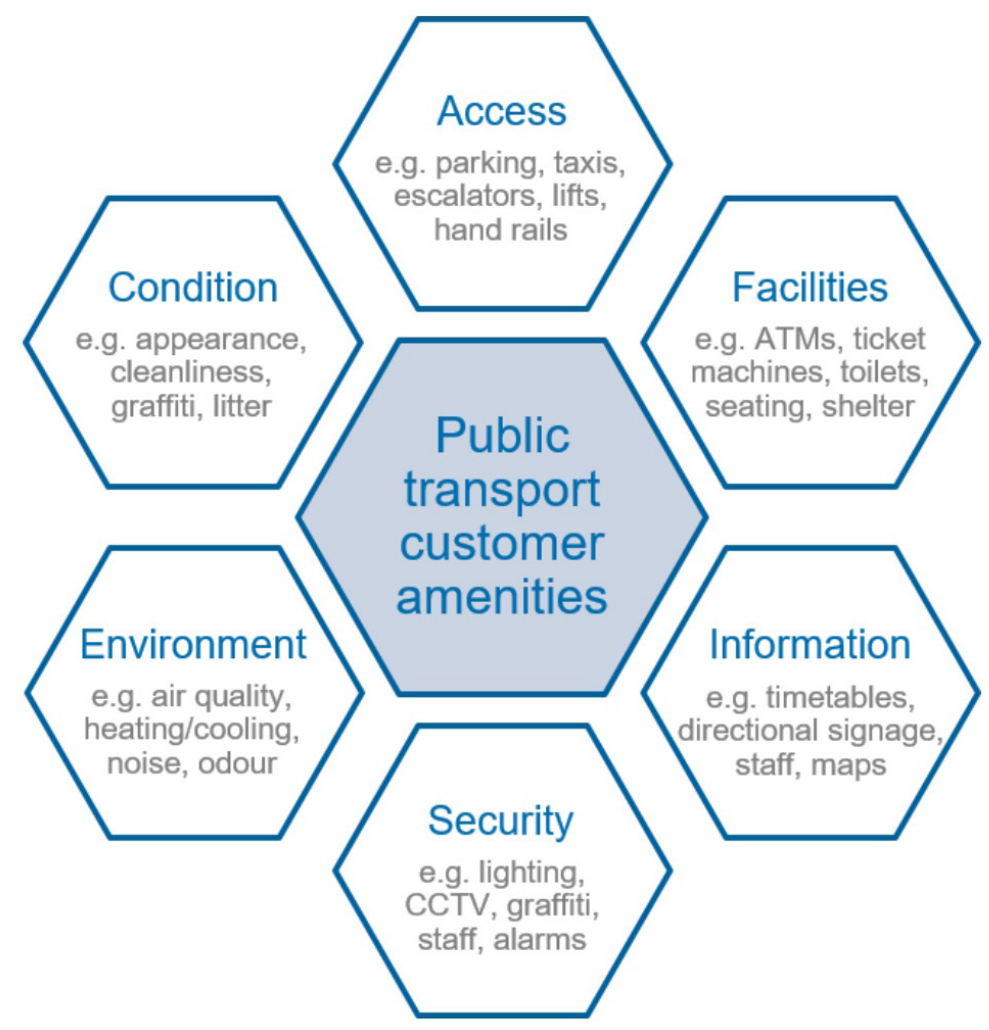

FIGURE 1.

Classification of public transport customer amenities Source: Public Transport Research Group (2017)

A feature of contemporary research innovation is to establish methods for estimating the value that public transport passengers place on different types of customer amenities (Douglas 2016; Fearnley, Flügel, and Ramjerdi 2011; Hensher and Prioni 2002; Molin and Timmermans 2006; Outwater et al. 2014; Phanikumar and Maitra 2006; Preston et al. 2008; Robson 2009; Steer Davies Gleave 2000; Wardman and Whelan 2001; Yoh et al. 2011), with selected values available in published guidelines (Balcombe et al. 2004; NZ Transport Agency 2016; Transport and Infrastructure Council 2017; Transport for London 2014). However, there is limited understanding of current practice across transit agencies in the use of customer amenity valuations in project appraisal. In particular, the extent to which agencies estimate and apply customer amenity values when appraising and evaluating different types of public transport projects is not well understood. A better understanding of current practice can help establish the relative importance of customer amenity valuations for project appraisal purposes and determine the extent to which customer amenities are considered across different types of public transport projects. Benchmarking can also be applied to identify areas of advanced practice across agencies, which may then guide the choice of methods adopted elsewhere.

This paper provides an overview of current practice across selected transit agencies in estimating and applying public transport customer amenity valuations. It is part of a wider research program exploring best practices in customer amenity valuation (Public Transport Research Group 2017). Key objectives include the following: 
Valuing Public Transport Customer Amenities: International Transit Agency Practice

- To determine the types of public transport projects that have been planned or delivered by transit agencies in the last 10 years

- To understand typical levels of appraisal that public transport projects have generally undergone and to what extent customer amenities have been included

- To understand the types of studies that have been undertaken for estimating the value of public transport customer amenities

- To understand the extent to which customer amenity values from previous studies have been applied in project appraisal, including the use of any published sources

The next section provides an overview of the literature relevant to public transport customer amenity valuation. An outline is then provided of the method used in a survey of transit agencies to determine current practice in estimating and applying public transport customer amenity valuations. Results of the survey are then presented, followed by some concluding remarks and a discussion of implications.

\section{Literature Review}

The literature review specifically covers valuation methods typically used in the field, issues associated with customer amenity valuation, and a high-level summary of reported values.

Stated preference (SP) has been the dominant method used to estimate the value of public transport customer amenities, although customer ratings have also been relatively common (De Gruyter et al. 2019). Other techniques include the priority evaluator method, revealed preference, and maximum difference (or best-worst) scaling. In some cases, multiple methods have been employed to value customer amenities. For example, stated preference has been combined with customer ratings so that the relative importance of different amenities, as rated by customers, can be applied to the willingness to pay estimates for overall vehicle and station/stop quality (Douglas Economics and Sweeney Research 2014). Despite the advantages of using revealed preference for valuing customer amenities, where consumer behavior is directly observed, relatively few studies have adopted this method given the difficulty in controlling for external factors that may additionally influence the customer experience (Robson 2009; Wardman and Whelan 2001). Notwithstanding the highly quantitative focus of customer amenity valuations, it is noted that other methods, particularly multicriteria analysis, have been commonly used in the appraisal of public transport projects given the need to incorporate benefits into the decision-making process that may be more difficult to quantify in practice (Henn et al. 2016).

A range of issues have been identified with the valuation of public transport customer amenities. A key issue relates to the high levels of variability inherent in the values themselves, which can make it difficult to transfer values from one service or city to another (Booz Allen \& Hamilton 2000). Differences in values can arise through changes in socioeconomic characteristics such as age, gender, and income, but can also be affected by trip purpose, frequency, length, and time of day (Fearnley et al. 2015; Phanikumar and Maitra 2007). Other key issues include changes in customer expectations and the relevance of amenities over time, which may affect the value ascribed to customer amenities as minimum standards increase and technology replaces some traditional forms of printed customer information (Outwater et al. 2014). As noted by Robson (2009), the quality of customer amenities may need to continually evolve and improve in order to stand still. An additional issue relates to the estimation of inflated valuations associated with the use of stated preference (Bristow et al. 1991). Survey respondents may overstate their valuations to influence policy or may indicate their preference for certain amenities and lose nothing by doing so, but in practice may not use those amenities at all (Robson 2009). 
A high-level summary of public transport customer amenity values is provided in Table 1 . This summary resulted from a collation of valuation evidence assembled as part of a wider research program. Some 556 separate customer amenity values were identified relating to 97 separate amenity types (De Gruyter et al. 2019). All the values were collated into a database that is available for free download to assist practitioners in this field (Public Transport Research Group 2017). The highly variable nature of valuations is evident in the relatively large range of values presented in Table 1. All median values are equivalent to less than one minute of in-vehicle time. The implication is that while customer amenities are of clear value to passengers, their value is generally small compared to overall travel time (typically 30-60 minutes). Relatively small differences in median values are found between amenity types, although "access" based amenities tend to be valued less for train/metro and tram/light rail than most other amenity types. In addition, "information" and "environment" based amenities tend to have higher median values for train/metro and bus than other amenity types. While tram/light rail based amenities tend to be valued lower than train/metro or bus, these are based on a much smaller sample of valuations.

\section{TABLE 1.}

High-Level Summary of Public Transport Customer Amenity Values, by Type and Mode

\begin{tabular}{lccc}
\hline \multirow{2}{*}{ Amenity type } & \multicolumn{3}{c}{ Median value (range in brackets): in-vehicle minutes } \\
\cline { 2 - 4 } Access & Train/metro & Tram/light rail & Bus \\
Facilities & $0.22(0.01-4.39)$ & $0.24^{*}$ & $0.64(0.05-5.59)$ \\
Information & $0.30(0.00-9.40)$ & $0.50(0.32-0.55)$ & $0.49(0.02-13.78)$ \\
Security & $0.50(0.03-12.01)$ & $0.30(0.09-0.65)$ & $0.61(0.02-11.35)$ \\
Environment & $0.73(0.03-6.79)$ & $0.45(0.22-0.50)$ & $0.62(0.00-13.43)$ \\
Condition & $0.40(0.00-13.99)$ & $0.48(0.32-0.55)$ & $0.53(0.02-13.78)$ \\
\hline
\end{tabular}

Source: Adapted from De Gruyter et al. (2019)

* Only one value was available, so no range can be presented.

\section{Research Method}

In order to meet the objectives of this research, a survey of selected transit agencies was undertaken during January-February 2018. The intent of the survey was to understand current practice across transit agencies in estimating and applying public transport customer amenity valuations. A total of 12 cities were targeted for the survey, including Melbourne, Sydney, Brisbane, Perth, Auckland, London, Paris, Toronto, San Francisco, Vienna, Oslo, and Singapore. Cities were selected that were generally comparable to Melbourne, where the research funding body is located, although some diversity in contexts was also sought.

Researchers spent considerable time identifying the most appropriate agency and representative in each city for completing the survey. Existing professional industry contacts were used where possible, along with Linkedln searches and the Transportation Research Board (TRB) online directory. Some "snowballing" to other contacts suggested by respondents also occurred. Follow-up telephone and email communication confirmed the relevant agency and contact person and ensured a common understanding of the survey questions and terms used. Only one survey completion was sought from each city, so the contacts had to possess sufficient knowledge of the agency's methods for public transport project appraisal, particularly the extent to which 
customer amenity valuations were considered. This was difficult in practice and some respondents spent time discussing responses within their agencies.

Following identification of the appropriate contact person in each agency, a link to an online version of the survey was sent via email. The survey included 11 questions and took approximately 20-30 minutes to complete. Where necessary, representatives were encouraged to liaise with others within their agency to complete the survey as accurately as possible so it would represent overall activity within that city. Survey questions were designed to align with the study objectives by asking agency representatives about the following:

- Types of public transport projects that were planned or delivered in their city (with involvement from their agency) in the last 10 years

- Typical levels of appraisal those public transport projects have generally undergone and to what extent customer amenities had been included

- Details of any studies the agency was involved in that estimated the value of public transport customer amenities in their city

- The extent to which customer amenity values from previous studies were applied in project appraisal, and any published sources that were used

While agencies may consider customer amenity valuations at different stages in project decision making (e.g., initially as part of considering all benefits vs. later to determine whether customer amenities should be included after a project has been approved), no distinction was made about this in the survey.

Table 2 lists the cities and associated agencies targeted for the survey and indicates which of these responded to the survey. As shown, 11 out of the 12 cities submitted a survey response. While several agency representatives were identified for San Francisco, this city did not respond within the survey time frame. Where responses were provided for other cities, agency representatives often had to coordinate input from others within their organization, which typically required several weeks. In Brisbane alone, more than 20 transit agency staff were involved in completing the survey.

\section{TABLE 2.}

Cities and Associated Transit Agencies Targeted for the Survey

\begin{tabular}{llc}
\hline City & Transit agency & Response received? \\
\hline 1. Melbourne & Transport for Victoria (TfV) & $\checkmark$ \\
2. Sydney & Transport for NSW (TfNSW) & $\checkmark$ \\
3. Brisbane & Department of Transport and Main Roads (TMR) & $\checkmark$ \\
4. Perth & Public Transport Authority of Western Australia (PTA) and & $\checkmark$ \\
5. Auckland & Department of Transport (DOT) & \\
6. London & Auckland Transport (AT) & $\checkmark$ \\
7. Paris & Tile-de-France Mobilités & $\checkmark$ \\
8. Toronto & Metrolinx & $\checkmark$ \\
9. San Francisco & San Francisco Municipal Transportation Agency (SFMTA) & $\checkmark$ \\
10. Vienna & City of Vienna & $\times$ \\
11. Oslo & Ruter & $\checkmark$ \\
12. Singapore & Land Transport Authority (LTA) & $\checkmark$ \\
\hline
\end{tabular}




\section{Results}

This section details the results of the transit agency survey. It is structured in line with the study objectives by focusing on the following aspects for each city:

- Types of public transport projects that have been planned/delivered

- Typical levels of appraisal of public transport projects

- Extent to which customer amenities are included in project appraisal

- Studies undertaken to estimate the value of customer amenities

- Extent to which customer amenity values from previous studies have been applied

- Published sources of customer amenity values that have been used

\section{Types of Public Transport Projects That Have Been Planned/Delivered}

Agency representatives were asked firstly about the types of public transport projects that have been planned and/or delivered in their city with involvement from their agency in the last 10 years. For each public transport mode (train/metro, tram/light rail, bus including bus rapid transit, and ferry), representatives were asked to select from the following project types:

- New or upgraded station/stop

- New or extended line/route

- New or refurbished rolling stock/vehicle

- Short-range planning (e.g., changes in frequency, operating hours, fares)

- Other project type(s)

Table 3 details the results, showing that agencies in all 11 cities had been involved in planning/delivering a range of train/metro and bus projects over the last 10 years. In general, all agencies were involved in a full range of train/metro projects and new/upgraded bus lines/extensions or new/upgraded bus stops. Involvement in different tram/light rail projects was less common, although several agencies (Melbourne, Sydney, Brisbane, London, Paris, and Vienna) reported involvement in all main types of projects concerning tram/light rail. Ferry projects were the least common, perhaps to be expected given their association with the presence of waterways in cities. 
TABLE 3.

Public Transport Projects Planned/Delivered in the Last 10 Years with Agency Involvement

\begin{tabular}{|c|c|c|c|c|c|c|c|c|c|c|c|c|c|}
\hline \multirow{2}{*}{ Mode } & \multirow{2}{*}{ Project type } & \multicolumn{11}{|c|}{ City } & \multirow{2}{*}{ Total } \\
\hline & & MEL & SYD & BNE & PER & AKL & LON & PAR & TOR & VIE & OSL & SIN & \\
\hline \multirow[t]{5}{*}{ Train/metro } & New or upgraded station/stop & $\checkmark$ & $\checkmark$ & $\checkmark$ & $\checkmark$ & $\checkmark$ & $\checkmark$ & $\checkmark$ & $\checkmark$ & $\checkmark$ & $\checkmark$ & $\checkmark$ & 11 \\
\hline & New or extended line/route & $\checkmark$ & $\checkmark$ & $\checkmark$ & $\checkmark$ & $\checkmark$ & $\checkmark$ & $\checkmark$ & $\checkmark$ & $\checkmark$ & $\checkmark$ & $\checkmark$ & 11 \\
\hline & New or refurbished rolling stock/vehicle & $\checkmark$ & $\checkmark$ & $\checkmark$ & $\checkmark$ & $\checkmark$ & $\checkmark$ & $\checkmark$ & $\checkmark$ & $\checkmark$ & $\checkmark$ & $\checkmark$ & 11 \\
\hline & Short range planning ${ }^{*}$ & $\checkmark$ & $\checkmark$ & $\checkmark$ & $\checkmark$ & $\checkmark$ & $\checkmark$ & $\checkmark$ & $\checkmark$ & $\checkmark$ & $\checkmark$ & $\checkmark$ & 11 \\
\hline & Other & & $\checkmark$ & & & $\checkmark$ & & & & & & & 2 \\
\hline \multirow[t]{5}{*}{ Tram/light rail } & New or upgraded station/stop & $\checkmark$ & $\checkmark$ & $\checkmark$ & & $\checkmark$ & $\checkmark$ & $\checkmark$ & & $\checkmark$ & $\checkmark$ & & 8 \\
\hline & New or extended line/route & $\checkmark$ & $\checkmark$ & $\checkmark$ & $\checkmark$ & $\checkmark$ & $\checkmark$ & $\checkmark$ & $\checkmark$ & $\checkmark$ & $\checkmark$ & & 10 \\
\hline & New or refurbished rolling stock/vehicle & $\checkmark$ & $\checkmark$ & $\checkmark$ & & & $\checkmark$ & $\checkmark$ & $\checkmark$ & $\checkmark$ & & & 7 \\
\hline & Short range planning ${ }^{\star}$ & $\checkmark$ & $\checkmark$ & $\checkmark$ & & & $\checkmark$ & $\checkmark$ & & $\checkmark$ & $\checkmark$ & & 7 \\
\hline & Other & & & & & & & & & & & & 0 \\
\hline Bus (incl. Bus & New or upgraded station/stop & $\checkmark$ & $\checkmark$ & $\checkmark$ & $\checkmark$ & $\checkmark$ & $\checkmark$ & $\checkmark$ & $\checkmark$ & $\checkmark$ & $\checkmark$ & $\checkmark$ & 11 \\
\hline \multirow[t]{4}{*}{ Rapid Transit) } & New or extended line/route & $\checkmark$ & $\checkmark$ & $\checkmark$ & $\checkmark$ & $\checkmark$ & $\checkmark$ & $\checkmark$ & $\checkmark$ & $\checkmark$ & $\checkmark$ & $\checkmark$ & 11 \\
\hline & New or refurbished rolling stock/vehicle & $\checkmark$ & $\checkmark$ & & $\checkmark$ & $\checkmark$ & $\checkmark$ & $\checkmark$ & $\checkmark$ & $\checkmark$ & $\checkmark$ & $\checkmark$ & 10 \\
\hline & Short range planning ${ }^{*}$ & $\checkmark$ & $\checkmark$ & $\checkmark$ & $\checkmark$ & $\checkmark$ & $\checkmark$ & $\checkmark$ & $\checkmark$ & $\checkmark$ & $\checkmark$ & $\checkmark$ & 11 \\
\hline & Other & & $\checkmark$ & & & $\checkmark$ & & & & & & & 2 \\
\hline \multirow[t]{5}{*}{ Ferry } & New or upgraded station/stop & $\checkmark$ & $\checkmark$ & $\checkmark$ & $\checkmark$ & $\checkmark$ & & & & & $\checkmark$ & & 6 \\
\hline & New or extended line/route & & $\checkmark$ & & & $\checkmark$ & & & & & $\checkmark$ & & 3 \\
\hline & New or refurbished rolling stock/vehicle & $\checkmark$ & $\checkmark$ & & & & $\checkmark$ & & & & $\checkmark$ & & 4 \\
\hline & Short range planning ${ }^{\star}$ & & $\checkmark$ & $\checkmark$ & $\checkmark$ & $\checkmark$ & & & & & $\checkmark$ & & 5 \\
\hline & Other & & & & & $\checkmark$ & & & & & & & 1 \\
\hline \multirow[t]{2}{*}{ Total } & & 14 & 18 & 13 & 11 & 16 & 13 & 12 & 10 & 12 & 15 & 8 & \\
\hline & & \multicolumn{2}{|c|}{$\begin{array}{l}\text { MEL = Melbourne } \\
\text { SYD = Sydney } \\
\text { BNE = Brisbane } \\
\text { PER = Perth } \\
{ }^{*} \text { Changes in frequ }\end{array}$} & \multicolumn{2}{|c|}{$\begin{array}{l}\text { AKL }=\text { Auckland } \\
\text { LON }=\text { London } \\
\text { PAR }=\text { Paris } \\
\text { TOR }=\text { Toronto }\end{array}$} & \multicolumn{2}{|c|}{$\begin{array}{l}\text { VIE = Vienna } \\
\mathrm{OSL}=\text { Oslo } \\
\text { SIN = Singapore }\end{array}$} & & & & & & \\
\hline
\end{tabular}

When the results are viewed by city, agencies located in Sydney, Auckland, and Oslo were involved in the greatest number of project types $(18,16$, and 15 respectively) with representation across all public transport modes, mainly because of their interest in ferries. This contrasts to the agency in Singapore (Land Transport Authority), which was involved in only train/metro and bus projects (total of eight project types).

\section{Typical Levels of Appraisal of Public Transport Projects}

For the types of public transport projects that agencies were involved with during the last 10 years, representatives were asked about the typical appraisal levels that those project types underwent. Response options for indicating the appraisal levels included the following:

- Advanced (e.g., economic evaluation)

- Intermediate (e.g., financial evaluation)

- Basic (e.g., mostly qualitative)

- No appraisal or evaluation

Table 4 details the results. Advanced (economic) appraisals were more common for train/metro and tram/ light rail projects than for bus or ferry projects. In addition, project appraisals for new or extended lines/routes for train/metro and tram/light rail were generally more advanced than those for refurbished rolling stock or short-range planning projects. While economic evaluation was noted as an example of an advanced appraisal, agencies may have also used other types of advanced appraisals, such as advanced forms of multicriteria analysis (Henn et al. 2016). 
TABLE 4.

Typical Appraisal Levels of Public Transport Projects in the Last 10 Years

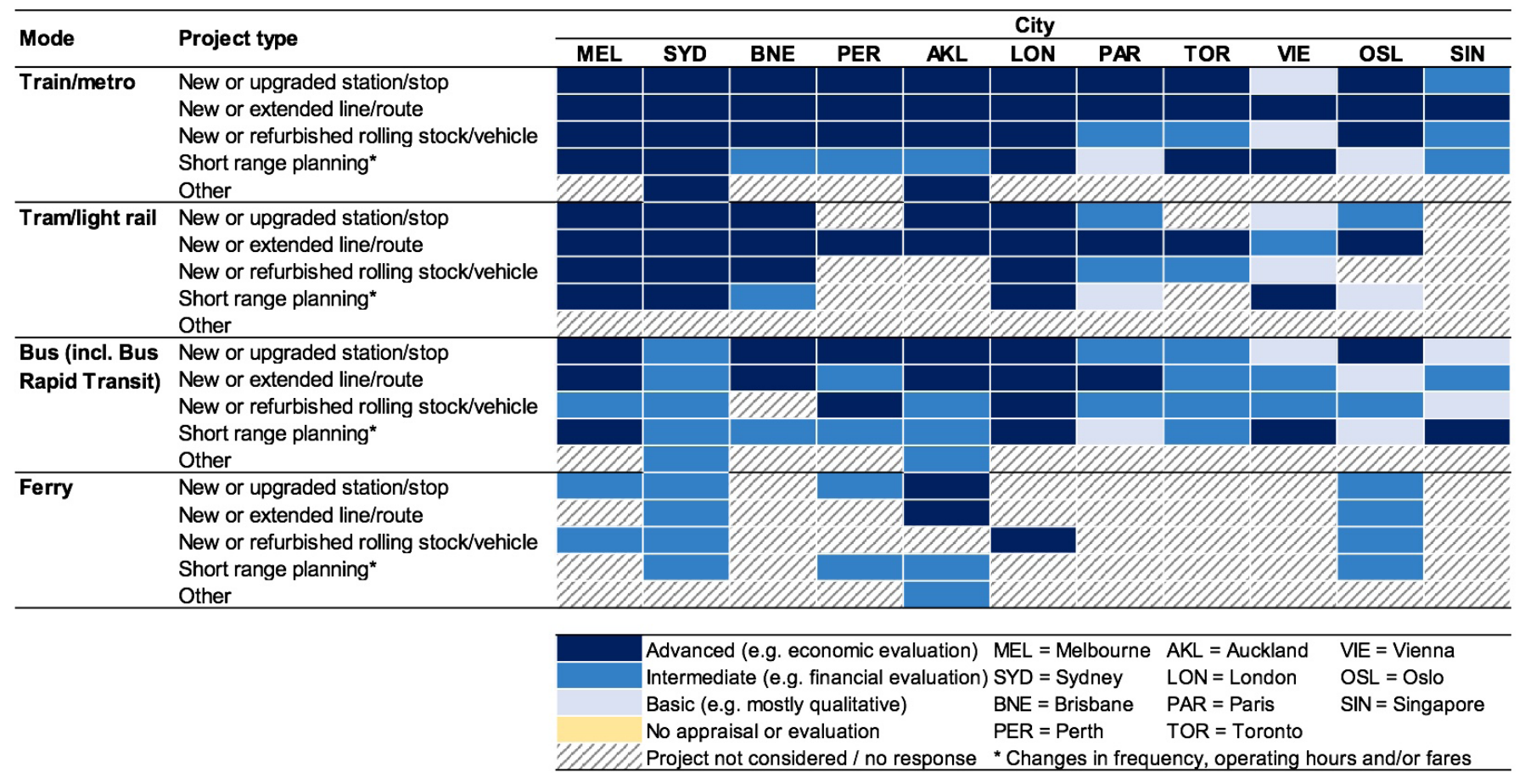

When the results are viewed by city, London (Transport for London) most commonly adopts an advanced level of appraisal across all relevant project types including buses. Melbourne comes in as a close second since it covers new/extended bus routes, stations/stops, and short-range bus planning. Other Australasian cities undertake advanced appraisals to a lesser extent; some cities, such as Sydney, tend to adopt only an intermediate (financial) analysis of bus projects. Most cities that have ferry projects also adopt intermediate analysis for those. Vienna and Oslo typically undertake lower levels of project appraisal compared to other cities. All cities use advanced levels of evaluation for new/extended train/metro lines.

\section{Extent to Which Customer Amenities Are Included in Project Appraisal}

For the types of public transport projects that agencies had been involved with during the last 10 years, representatives were asked about the extent to which customer amenities were typically included in project appraisal. Response options ranged from "never" to "80-100\% of the time." Table 5 details the results, which reveal considerable variation in the extent to which customer amenities were included in appraisals. 
TABLE 5.

Extent to Which Customer Amenities Were Included in Public Transport Project Appraisal in the Last 10 Years

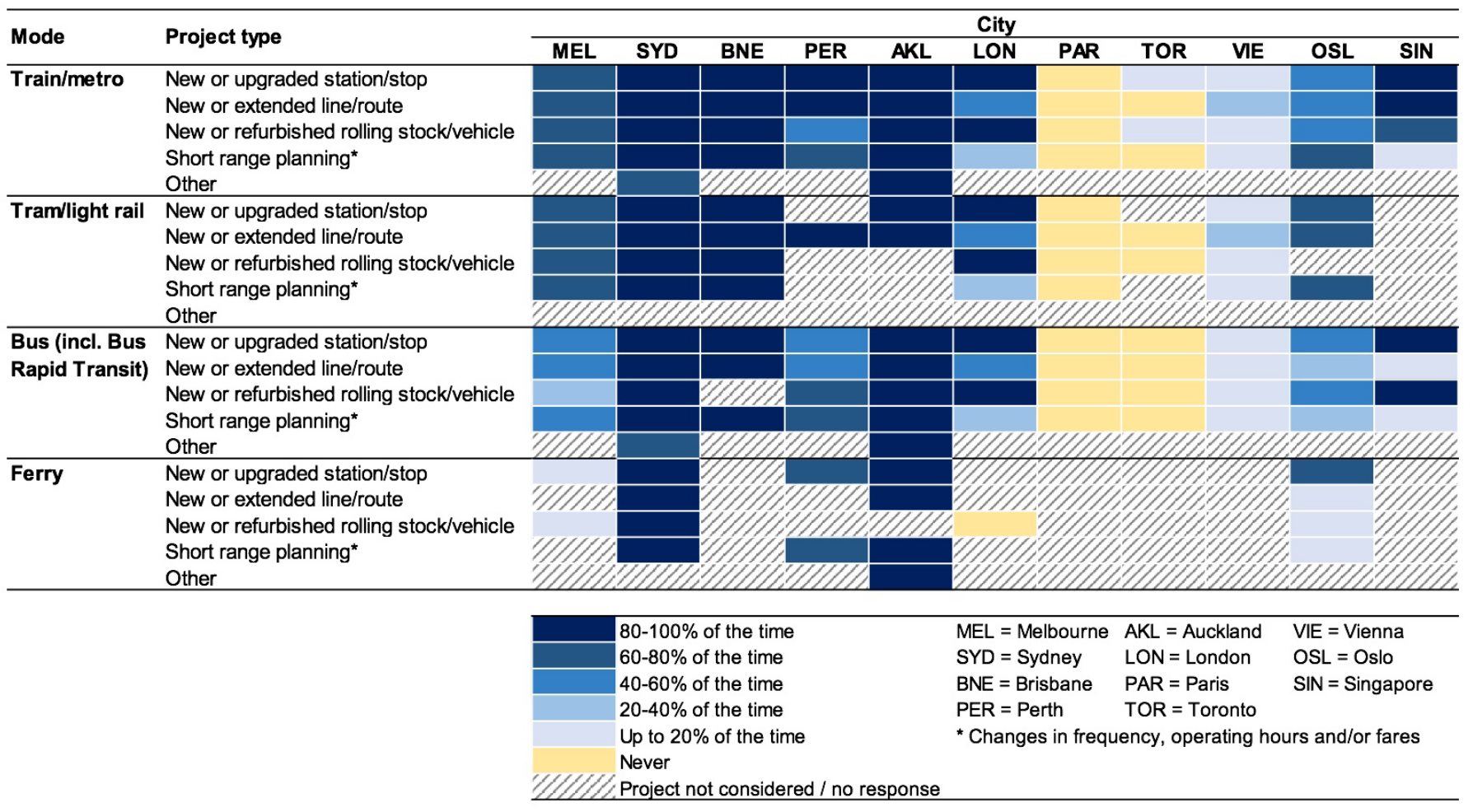

Sydney, Brisbane, and Auckland reported that they almost always (generally $80-100 \%$ of the time) include customer amenities in the appraisal of public transport projects. Melbourne and to an extent Perth contrast these Australasian cities since they do this only $60-80 \%$ of the time for train/tram projects and $40-60 \%$ of the time for bus projects. London and Singapore include amenities in appraisals of new bus and train/metro stations and somewhat for bus/rail rolling stock. For London, this is done at lower levels for other public transport projects and in Singapore, amenities are generally not considered for other project types. Paris never includes amenities in project appraisals and Toronto rarely does, only for train/metro station upgrades and new/refurbished rolling stock.

The extent to which customer amenities are included in appraisals in Sydney and Brisbane are supported by the following comments made by agency representatives in these cities:

Transport for NSW espouses that [the] customer is the centre of everything we do in Transport. In every program or project, the project proponent and the evaluators ask the question, "How will this affect the customers?" Thus, my area always looks for the best practice or method in defining and measuring customer amenity and CVP [Customer Value Proposition] so that this aspect is continuously included in cost benefit analysis (CBA). [Response from agency representative in Sydney]

TMR values customer feedback, which assists in the valuation of public transport customer amenities to improve the transport network. [Response from agency representative in Brisbane]

While customer amenities are considered in project appraisal in Perth, albeit not to the same extent as Sydney/ Brisbane, the importance placed on customer amenities in this city was also highlighted:

The vast majority of PT project assessment is undertaken within PTA [and] is very focused on the many strands of customer amenity. At a high level, its strategic approach could perhaps best 
be described that PTA seeks to maintain high standards for amenity in many regards across its existing PT operations, and then ensure these equivalent standards are maintained. Some key points: passenger perceptions are annually measured through Canstar surveys; police are on all late night train services; Transperth has strong bus-train connectivity with fully integrated ticketing and timetables; there is a high quality of information available through various channels on timetables and other relevant issues such as major events, real-time disruptions; old stations are slowly being upgraded to ensure full disability access. [Response from agency representative in Perth]

Using the results from Tables 4 and 5, Table 6 explores project types where an "advanced" level of appraisal is used (Table 4) and assesses the extent to which customer amenities have been included in those appraisals (e.g., "never" to " $80-100 \%$ of the time"). The aim is to highlight the extent to which customer amenities are included in advanced levels of appraisal.

\section{TABLE 6.}

Difference Between Advanced Levels of Appraisal and Inclusion of Customer Amenities

\begin{tabular}{|c|c|c|c|c|c|c|c|c|c|c|c|c|}
\hline \multirow{2}{*}{ Mode } & \multirow{2}{*}{ Project type } & \multicolumn{11}{|c|}{ City } \\
\hline & & MEL & SYD & BNE & PER & AKL & LON & PAR & TOR & VIE & OSL & SIN \\
\hline \multirow[t]{5}{*}{ Train/metro } & New or upgraded station/stop & & & & & & & & & & & \\
\hline & New or extended line/route & & & & & & & & & & & \\
\hline & New or refurbished rolling stock/vehicle & & & & & & & & & & & \\
\hline & Short range planning ${ }^{\star}$ & & & & & & & & & & & \\
\hline & Other & & & & & & & & & & & \\
\hline \multirow[t]{5}{*}{ Tram/light rail } & New or upgraded station/stop & & & & & & & & & & & \\
\hline & New or extended line/route & & & & & & & & & & & \\
\hline & New or refurbished rolling stock/vehicle & & & & & & & & & & & \\
\hline & Short range planning ${ }^{*}$ & & & & & & & & & & & \\
\hline & Other & & & & & & & & & & & \\
\hline \multirow{5}{*}{$\begin{array}{l}\text { Bus (incl. Bus } \\
\text { Rapid Transit) }\end{array}$} & New or upgraded station/stop & & & & & & & & & & & \\
\hline & New or extended line/route & & & & & & & & & & & \\
\hline & New or refurbished rolling stock/vehicle & & & & & & & & & & & \\
\hline & Short range planning ${ }^{*}$ & & & & & & & & & & & \\
\hline & Other & & & & & & & & & & & \\
\hline \multirow[t]{5}{*}{ Ferry } & New or upgraded station/stop & & & & & & & & & & & \\
\hline & New or extended line/route & & & & & & & & & & & \\
\hline & New or refurbished rolling stock/vehicle & & & & & & & & & & & \\
\hline & Short range planning ${ }^{*}$ & & & & & & & & & & & \\
\hline & Other & & & & & & & & & & & \\
\hline
\end{tabular}

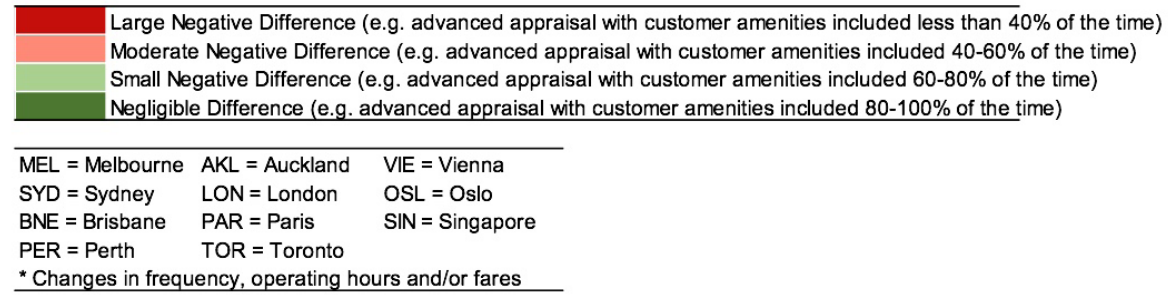

In general, the share of appraisals using customer amenities for advanced project appraisals is relatively low. They are illustrated in Table 6 and defined as follows:

- Negligible difference: where an advanced level of appraisal includes high levels of amenity adoption (80$100 \%$, dark green)

- Small negative difference: where advanced levels of appraisal are undertaken but with only $60-80 \%$ of projects including customer amenities (light green) 
- Moderate negative difference: where advanced levels of appraisal are undertaken but with only 40-60\% of projects including customer amenities (light red)

- Large negative difference: where advanced levels of appraisal are undertaken but low levels of amenities are included (less than $40 \%$ including never, dark red)

The Australasian cities-Sydney, Brisbane, Auckland, and to some extent Perth—generally include customer amenities as part of advanced appraisals for all relevant project types. Melbourne stands out relative to other Australasian cities as including customer amenities less frequently in appraisals of train/tram projects. Australasian practice tends to include customer amenities more frequently in project appraisals than London, which tends to incorporate amenities in a smaller share of advanced appraisals. Table 6 also highlights that Paris, Toronto, and Vienna adopt advanced evaluations for some projects but rarely include customer amenities in these appraisals. Indeed, Paris and to an extent Toronto do not typically include customer amenities in their advanced appraisals.

\section{Studies Undertaken to Estimate the Value of Customer Amenities}

Representatives were asked if their agencies had ever been involved in making their own estimates of the value of public transport customer amenities in their cities, either through commissioning external providers or undertaking valuation studies in-house. The results revealed that valuation studies had been commissioned/ undertaken by agencies in 7 out of the 11 surveyed cities, including Melbourne, Sydney, Brisbane, London, Paris, Oslo, and Singapore.

Agency representatives in Auckland, Toronto, Perth, and Vienna did not report any original local primary research studies valuing amenities. Of the agencies that had commissioned or undertaken valuation studies, representatives were asked to provide details for up to five of the most recent studies. Table 7 provides a summary of the results.

TABLE 7.

Studies Undertaken to Estimate the Value of Public Transport Customer Amenities

\begin{tabular}{|c|c|c|c|c|c|c|c|c|c|c|c|c|c|c|}
\hline City & $\begin{array}{l}\text { Survey } \\
\text { year/s }\end{array}$ & \multicolumn{4}{|c|}{ Public transport mode/s } & \multicolumn{6}{|c|}{ Survey method/s } & \multicolumn{3}{|c|}{ Who primarily undertook the valuation? } \\
\hline Melbourne & 2014 & $\checkmark$ & $\checkmark$ & $\checkmark$ & & $\checkmark$ & & $\checkmark$ & & & $\checkmark$ & & $\checkmark$ & \\
\hline \multirow[t]{4}{*}{ Sydney } & $\begin{array}{l}2015 \\
2012\end{array}$ & $\begin{array}{l}\checkmark \\
\checkmark \\
\checkmark\end{array}$ & $\checkmark$ & $\checkmark$ & $\checkmark$ & $\checkmark$ & & & & & $\checkmark$ & $\checkmark$ & $\checkmark$ & \\
\hline & Annual & $\checkmark$ & $\checkmark$ & $\checkmark$ & $\checkmark$ & & & $\checkmark$ & & & $\checkmark$ & $\checkmark$ & & \\
\hline & 2016 & $\checkmark$ & & & & & & & & & $\checkmark$ & & $\checkmark$ & \\
\hline & 2015 & & & $\checkmark$ & & $\checkmark$ & & & & & & & $\checkmark$ & \\
\hline Brisbane & Ongoing & $\checkmark$ & & $\checkmark$ & $\checkmark$ & & & & & & $\checkmark$ & $\checkmark$ & & \\
\hline \multirow{4}{*}{ London } & 2014 & $\checkmark$ & $\checkmark$ & $\checkmark$ & & $\checkmark$ & & & & & & & $\checkmark$ & \\
\hline & 2013 & & & & & $\checkmark$ & & & & & & & $\checkmark$ & \\
\hline & 2011 & $\checkmark$ & $\checkmark$ & $\checkmark$ & & $\checkmark$ & & & & & & & $\checkmark$ & \\
\hline & 2007 & $\checkmark$ & $\checkmark$ & $\checkmark$ & & $\checkmark$ & & & & & & & $\checkmark$ & \\
\hline \multirow[t]{2}{*}{ Paris } & 2005 & $\checkmark$ & & & & $\checkmark$ & & & & & & & $\checkmark$ & \\
\hline & 2013 & $\checkmark$ & $\checkmark$ & $\checkmark$ & & $\checkmark$ & $\checkmark$ & & & $\checkmark$ & & & $\checkmark$ & \\
\hline Oslo & 2015 & $\checkmark$ & $\checkmark$ & $\checkmark$ & $\checkmark$ & & $\checkmark$ & & & & $\checkmark$ & & & $\checkmark$ \\
\hline
\end{tabular}

Note: No valuation studies were reported for Perth, Auckland, Toronto, or Vienna 
Key observations from Table 7 include the following:

- Of the 17 total valuation studies reported across all cities, Sydney and London reported the largest number ( 5 each), in addition to Brisbane, which reported studies on an ongoing/annual basis; other cities had only 1-2 studies each.

- Most valuation studies had been undertaken within the last 5 years (13 out of 17 studies) with almost all undertaken within the last 10 years (15 out of 17 studies).

- Most studies considered customer amenities for train/metro (15 studies) and to a lesser extent bus (13 studies) and tram/light rail (11 studies); only 5 studies were concerned with ferry based customer amenities, perhaps reflective of the physical geography (waterways) of the cities.

- "Stated preference" was the most common survey method (used in 11 out of 17 studies); while "other" methods were used in 7 studies, these were often associated with utilization and satisfaction surveys.

- Consultants/contractors primarily undertook the valuations (12 out of 17 studies); the remainder were undertaken in-house or by a university/research institute.

While no valuation studies were reported for Perth, the importance of valuing customer amenities was highlighted by an agency representative in this city:

I think it is important to value these elements as they are often undervalued in relation to people's perception and use of PT. [Response from agency representative in Perth]

Comments were also made regarding the use of ratings as part of valuing customer amenities, as well as the usefulness of customer amenity valuations in public transport project appraisal:

We do link some defined levels [for attributes] to a 0-100 scale rating and can undertake mystery shopper assessments to link to benefit realisation and see the actual improvement in ratings after implementing a scheme. Adds significantly to robustness in prediction and neatly links to benefit realisation and evaluation... Amenity scores are often quite small in the grand scheme of things, but they are useful in deciding what people want/prioritise. They are useful for continually improving designs and for asset refurbishments. They are less useful for justifying line extensions but help refine the designs. [Response from agency representative in London]

\section{Extent to Which Customer Amenity Values from Previous Studies Have Been Applied}

For the types of public transport projects that agencies had been involved with during the last 10 years, representatives were asked about the extent to which customer amenity values from previous studies had been applied for project appraisal purposes (a technique known as benefit/value transfer). Table 8 details the results. Not all agency representatives had enough information/knowledge to answer this question and as a result, responses could be obtained for only 8 out of the 11 cities. 
TABLE 8.

Extent to Which Values from Previous Studies Have Been Applied in Project Appraisal in the Last 10 Years

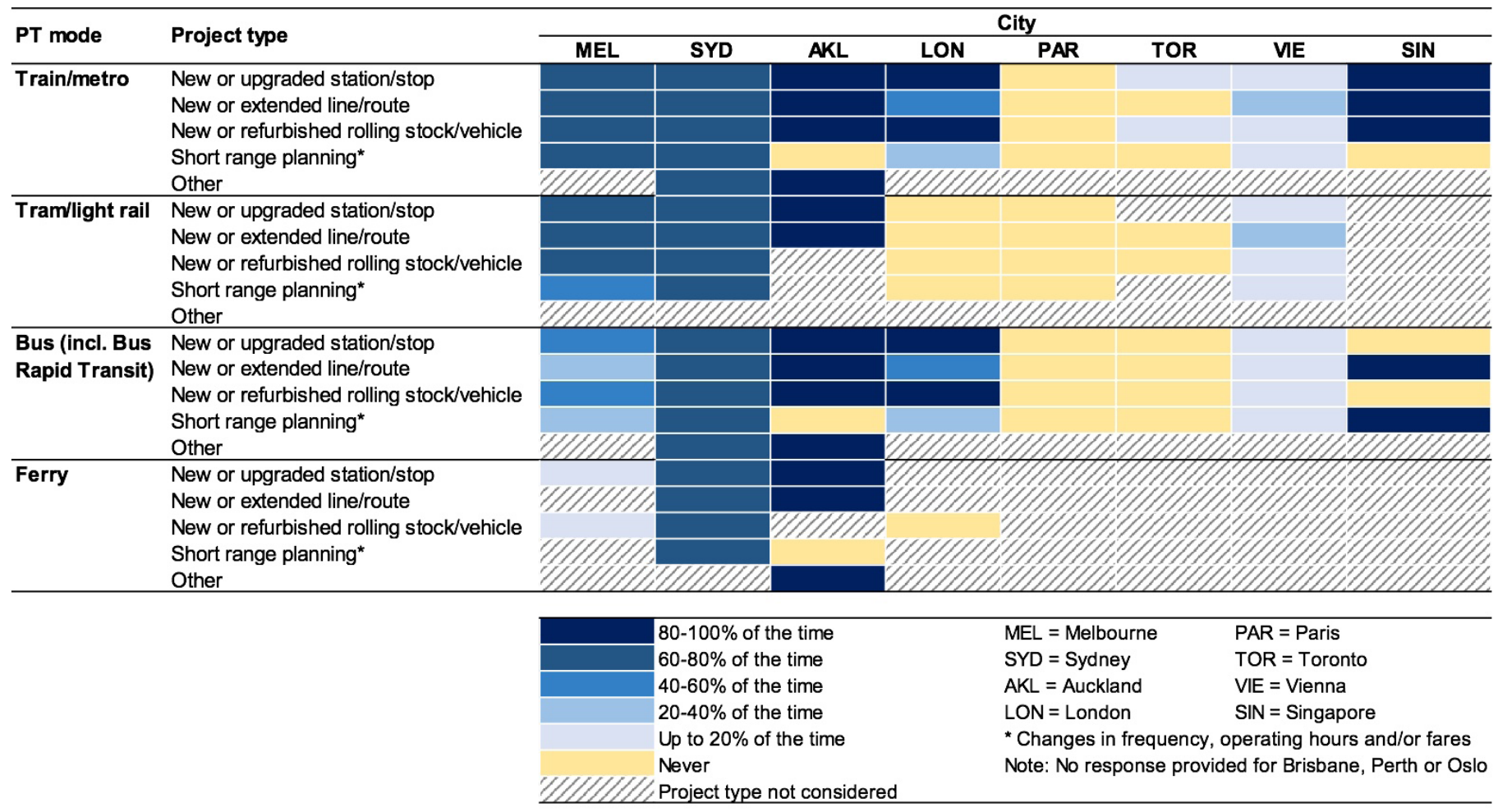

In general, cities where customer amenities are used in appraisals (Table 5) more commonly adopt values from previous studies. Paris and Toronto, where amenities are not typically included in appraisals, tend not to use values from previous studies (as might be expected).

While customer amenity values from previous studies are commonly adopted in some cities, one agency representative highlighted the difficulties associated with doing so:

It is difficult to gauge the extent of improvement in our project cases and relate them to the amenity improvements stated in the published research. There are framing effects and customer experience with alternative transport systems which no doubt play into stated preference responses. The combined effect of multiple simultaneous amenity improvements (e.g., halo effects) is difficult to accurately gauge. It is also a worry that published amenity research (either public or from consultants) tends not to publish full logit model specifications and standard errors, making it impossible to assess whether the amenity values quoted are statistically significant, and what the resulting forecasting error might be. [Response from agency representative in Melbourne]

While valuation studies have been undertaken in Paris, as noted earlier, the agency representative in this city noted that the results were not sufficiently robust to be incorporated in project appraisal but that customer amenities were still considered in an indirect manner:

We published two sets of papers during the last decade on the valuation of regularity... and crowding... Reference values of our appraisals come from these studies. Both are based on SP surveys. The last one includes a set of questions displaying cleanliness, temperature, noise, accessibility, 
stability on board, using Best Worst Scaling methods... We considered, however, the results not robust enough to be implemented in our appraisal methods. Customer amenities as they are depicted in this survey are not directly taken into account for our evaluations. They take part indirectly in the generalized cost of trips estimated from our traffic model in a sense that it includes specific modal parameters for train, metro or aerial modes (bus/tram) in utility functions... Amenity valuations are becoming a great concern for us, mainly in the perspective of ex-post evaluations of several measures. [Response from agency representative in Paris]

\section{Published Sources of Customer Amenity Values That Have Been Used}

Representatives were asked if their agencies use any published sources of public transport customer amenity values. The results revealed that published sources are used in 7 of the 11 cities (Melbourne, Sydney, Perth, Auckland, London, Toronto, and Singapore) and include the following:

- Australian Transport Assessment and Planning Guidelines (Transport and Infrastructure Council 2017): used in Melbourne, Sydney, and Perth

- Business Case Development Manual (London Transport 1997; Transport for London 2014): London, Toronto, and Singapore

- Economic evaluation manual (NZ Transport Agency 2016): Auckland

- Guide to Project Evaluation (Austroads 2012): Sydney

- National Guidelines for Transport System Management in Australia (Australian Transport Council 2006): Melbourne, Sydney, and Perth

- Passenger Demand Forecasting Handbook (British Railways Board 1994): London

- The demand for public transport: a practical guide (Balcombe et al. 2004): Sydney

- Transport Analysis Guidance (Department for Transport 2017): Sydney

While agencies generally reported using published sources specific to their country, it is noted that agencies located in Toronto and Singapore use customer amenity values from London (Transport for London 2014), with Sydney adopting values from both the United Kingdom (Balcombe et al. 2004; Department for Transport 2017) and Australia (Australian Transport Council 2006; Austroads 2012; Transport and Infrastructure Council 2017). The agency representative in Toronto commented on the use of customer amenity values from London, but also the desire to estimate local values in the future:

We have only recently started incorporating customer amenity valuations into our appraisal practices. We have been relying on Transport for London's Business Case Development Manual to understand the value of platform canopies, Wi-Fi on trains, improvement in weather protection while waiting on train platforms, improvement in information provision, etc. We are hoping to undertake our own research in the near future to localize some of these willingness-to-pay parameters/time saving factors with respect to improvements in customer amenities. [Response from agency representative in Toronto]

\section{Conclusion}

The aim of this paper was to provide an overview of current practice across selected transit agencies in estimating and applying public transport customer amenity valuations in project appraisal. A survey of transit agencies across 11 cities was undertaken to achieve this aim. This final section of the paper provides a summary of the results and a brief discussion of the implications for practice. 
Agencies in each of the 11 cities reported their involvement in a considerable range of train/metro and bus projects. The extent of involvement in tram/light rail and ferry projects in cities is lower and likely related to whether a city has these modes of public transport. Levels of appraisal (advanced, intermediate, basic) varied across cities and in terms of the type of public transport project being considered. This may in part reflect the findings of Henn et al. (2016), where benefits that are more difficult to quantify in practice tend to be included in public transport project appraisals using more qualitative (basic) methods.

For train/metro and tram/light rail projects, the Australasian cities-Sydney, Brisbane, Auckland, and to an extent Perth-generally have widespread inclusion of customer amenities as part of advanced appraisals for relevant project types. Relative to other Australasian cities, Melbourne included customer amenities less frequently in appraisals of train/tram projects. Australasian practice tends to include customer amenities more frequently in project appraisal than London, which tends to incorporate amenities in a smaller share of advanced appraisals. Paris, Toronto, and Vienna adopt advanced appraisals for some projects, but rarely include customer amenities in these appraisals.

Information relating to 17 valuation studies was provided by agency representatives across seven cities. Most of the studies were undertaken in the last five years, suggesting a possible greater emphasis on customer amenities by transit agencies. Consultants/contractors undertook most of the valuation studies, which may highlight the need to ensure that agencies have adequate in-house skills and resources to correctly interpret and apply the outputs of such studies. Agency representatives in Auckland, Toronto, Perth, and Vienna did not report any original local primary research studies valuing amenities in their cities.

In general, cities that use amenities in appraisals more commonly adopt values from previous studies. Published sources of customer amenity values are used by agencies in 7 out of the 11 cities and while agencies generally use sources specific to their country, Toronto and Singapore (and to some extent Sydney) use values from London. This finding may suggest a lack of customer amenity values available in these cities and that local valuation studies are needed to fill this gap. While London's customer amenity values tend to be used internationally, it is noted that Transport for London tends to incorporate customer amenity values in advanced appraisals less than some cities, particularly those in Australasia. While Transport for London noted that "amenity scores are often quite small in the grand scheme of things," further research should be undertaken to better understand why agencies that have local customer amenity values choose not to use them in some advanced appraisals.

While this research has provided an understanding of current practice across transit agencies in estimating and applying public transport customer amenity valuations, it is limited to the practice of 11 cities. Furthermore, while considerable effort was taken to ensure each survey response represented practice across each agency, the responses are limited to the information and knowledge available by those completing the survey. Further research is needed, potentially using a similar methodology, to better understand the use of customer amenity valuations in other jurisdictions, particularly cities located throughout North America, South America, and Asia. It is also acknowledged that cultural norms and common language may have influenced the research findings, particularly in cities where English is not an official language (Paris, Vienna, Oslo), despite best efforts to ensure that agency representatives had a clear understanding of the survey questions and terms used. Nevertheless, this paper sheds important light on current practice in selected cities in the field of public transport customer amenity valuation and helps to establish the current state of play in this area. Future research is also needed to understand best practice in the field of public transport customer amenity valuation. 


\section{Acknowledgments}

Sincere thanks go to each of the survey participants for their valuable input and time. The findings reported in this paper are part of a wider research project funded by Transport for Victoria (TfV) on best practice approaches in public transport customer amenity valuation. Many thanks for assistance from Adrian Webb of $\mathrm{TfV}$ with this work.

\section{References}

Australian Transport Council. 2006. National Guidelines for Transport System Management in Australia, Volume 4: Urban Transport. Canberra, Australia: Commonwealth of Australia.

Austroads. 2012. Guide to Project Evaluation. Syndey: Austroads, Ltd.

Balcombe, R., R. Mackett, N. Paulley, J. Preston, J. Shires, H. Titheridge, M. Wardman, and P. White. 2004. The demand for public transport: a practical guide. Report TRL593. London: TRL Limited.

Booz, Allen \& Hamilton. 2000. Valuation of Public Transport Attributes. New Zealand: Transfund New Zealand.

Bristow, A. L., P. G. Hopkinson, C. Nash, and M. Wardman. 1991. "Evaluation of the Use and Non-Use Benefits of Public Transport: Report No. 1 - Development of a survey methodology." Working Paper 309. Institute of Transport Studies, University of Leeds.

British Railways Board. 1994. Passenger Demand Forecasting Handbook. United Kingdom: British Railways Board.

Currie, G., R. Scott, and K. Tivendale. 2013. Experience with value-for-money urban public transport system enhancements. NZ Transport Agency research report 531, Wellington, New Zealand.

De Gruyter, C., G. Currie, L. T. Truong, and F. Naznin. 2019. "A meta-analysis and synthesis of public transport customer amenity valuation research." Transport Reviews 39 (2): 261-283. doi:10.1080/01441647.2018.1461708.

Department for Transport. 2017. Transport Analysis Guidance (TAG). London: Department for Transport.

Douglas Economics and Sweeney Research. 2014. Information \& Service Quality Values for Public Transport in Melbourne. Public Transport Victoria, Melbourne, Australia.

Douglas, N. 2016. Pricing strategies for public transport, Part 1. NZ Transport Agency research report 565, Wellington, New Zealand.

Fearnley, N., J. Aarhaug, S. Flügel, J. Eliasson, and A. Madslien. 2015. "Measuring the patronage impact of soft quality factors in urban public transport." Presentation at ITEA Annual Conference, Oslo, Norway.

Fearnley, N., S. Flügel, and F. Ramjerdi. 2011. "Passengers' valuations of universal design measures in public transport." Research in Transportation Business \& Management 2 (November 2011): 83-91. doi:10.1016/j. rtbm.2011.07.004.

Henn, L., K. Sloan, M. B. Charles, and N. Douglas. 2016. "An appraisal framework for evaluating financing approaches for public infrastructure." Public Money \& Management 36 (4): 273-280. doi:10.1080/09540962.2 016.1162595.

Hensher, D., and P. Prioni. 2002. "A Service Quality Index for Area-wide Contract Performance Assessment." Journal of Transport Economics and Policy 36 (1): 93-113.

London Transport. 1997. Business Case Development Manual. London: LT Corporate Planning. 
Molin, E. J. E., and H. J. P. Timmermans. 2006. "Traveler expectations and willingness-to-pay for Web-enabled public transport information services." Transportation Research Part C: Emerging Technologies 14 (2): 57-67. doi:10.1016/j.trc.2006.05.003.

NZ Transport Agency. 2016. Economic evaluation manual. NZ Transport Agency, Wellington, New Zealand.

Outwater, M., B. Sana, N. Ferdous, B. Woodford, J. Lobb, D. Schmitt, et al. 2014. Characteristics of Premium Transit Services that Affect Choice of Mode. Transit Cooperative Research Program (TCRP) Report 166. Washington, DC: The National Academies Press. https://doi.org/10.17226/22401.

Phanikumar, C. V., and B. Maitra. 2006. "Valuing Urban Bus Attributes: An Experience in Kolkata." Journal of Public Transportation 9 (2): 69-87. http://doi.org/10.5038/2375-0901.9.2.4.

Phanikumar, C. V., and B. Maitra. 2007. "Willingness-to-Pay and Preference Heterogeneity for Rural Bus Attributes." Journal of Transportation Engineering 133 (1): 62-69. https://doi.org/10.1061/(ASCE)0733947X(2007)133:1(62).

Preston, J., S. Blainey, G. Wall, M. Wardman, C. V. Phanikumar, C. Heywood, and R. Sheldon. 2008. "The effects of station enhancements on rail demand." Paper presented at European Transport Conference, Noordwijkerhout, Netherlands.

Public Transport Research Group. 2017. "Best Practice Approaches to Public Transport Customer Amenity Valuation." Monash University. Accessed June 14, 2018. http://publictransportresearchgroup.info/portfolioitem/best-practice-approaches-to-public-transport-customer-amenity-valuation/.

Robson, S. 2009. The Role of Soft Measures in Influencing Patronage Growth and Modal Split in the Bus Market in England. Final Report, Department for Transport. Cheshire, UK: AECOM.

Steer Davies Gleave. 2000. Rail Passenger Quality of Service Valuations. Shadow Strategic Rail Authority, London.

Transport and Infrastructure Council. 2017. Australian Transport Assessment and Planning Guidelines: M1 Public Transport (Draft for public consultation). Department of Infrastructure and Regional Development, Canberra, Australia.

Transport for London. 2014. Business Case Development Manual. London: TfL Programme Management Office.

Wardman, M., and G. Whelan. 2001. "Valuation of improved railway rolling stock: A review of the literature and new evidence." Transport Reviews 21 (4): 415-447. doi:10.1080/01441640010020115.

Yoh, A., H. Iseki, M. Smart, and B. D. Taylor. 2011. "Hate to Wait: Effects of Wait Time on Public Transit Travelers' Perceptions." Transportation Research Record: Journal of the Transportation Research Board 2216 (1): 116124. https://doi.org/10.3141/2216-13. 


\section{About the Authors}

Chris De Gruyter (chris.degruyter@rmit.edu.au) is a Vice-Chancellor's Research Fellow in the Centre for Urban Research at RMIT University. His current research focus is exploring the impacts of new land use development on public transport. Prior to joining RMIT University, Chris was a Research Fellow in the Public Transport Research Group at Monash University. He also worked in transport planning for 12 years, both with the Victorian government and in consulting.

Graham Currie (graham.currie@monash.edu) is an international public transport research leader and policy advisor with more than 30 years of experience. He has published extensively in leading international peer research journals in this field. He is also founder of the World Transit Research clearinghouse (www. worldtransitresearch.info), which has consolidated all research in this field into a single accessible source that is used by more than 8,000 towns and cities in more than 170 countries worldwide. Professor Currie has worked for some of the world's leading public transport operators including London Transport and he has managed numerous public transport research and development projects internationally. 